\begin{tabular}{|c|c|c|}
\hline & $\begin{array}{c}\text { Journal of Integrated and Advanced Engineering } \\
\text { (JIAE) }\end{array}$ & \\
\hline A S A S I & $\begin{array}{l}\text { Vol. 1, No. 1, March 2021: 21-28 } \\
\text { http://asasijournal.id/index.php/jiae } \\
\text { http://doi.org/10.51662/jiae.v1i1.9 }\end{array}$ & \\
\hline
\end{tabular}

\title{
Building a Prototype of an Eco-friendly House in the Peri-Urban Area
}

\author{
Allis Nurdini ${ }^{1 *}$, Endra Susila ${ }^{2}$, Taufik Taufikurahman ${ }^{3}$, Nur Fitra Hadianto ${ }^{4}$, \\ Maryam Al Lubbu ${ }^{5}$, Asih Suryati ${ }^{6}$ \\ 1,2,3,4,5,6 Center for Rural Empowerment, Institut Teknologi Bandung, Indonesia \\ ${ }^{1}$ School of Architecture, Planning and Policy Development, Institut Teknologi Bandung, Indonesia \\ ${ }^{2}$ Faculty of Civil and Environment Engineering, Institut Teknologi Bandung, Indonesia \\ ${ }^{3}$ School of Life Sciences and Technology, Institut Teknologi Bandung, Indonesia
}

\begin{abstract}
The concept of sustainable housing has considered the urgency to support the sustainable environment in an integrative way. This concept is related to several main principles include environmental, social, and economic sustainability. In practice, these principles translated into the fundamental of housing choice, both process and product choices. In many peri-urban areas, current house construction tends to imitate city houses with massive concrete structures equipped with air conditioning that caused high energy consumption. The Center for Rural Empowerment team of ITB built a prototype of an eco-friendly house in Haurgombong village, Sumedang, West Java. The house has two floors building on a $7 \times 5 \mathrm{~m} 2$ land site. The first floor was renovated from the existing toilet rooms and develop into a two-floor house. The second floor was built using the local wood material. The wood material has been obtaining from the trees of seven years old beechwood (Gmelina Arborea) planted in the garden. The envelope material for this house was constructed from local and common material in rural or peri-urban context, the lightweight fiberglass for the roof of common room, and the transparent fiber materials for the roof of secondfloor terrace to make the plantation at this area can easily receive the sunlight. This house is also can be regarded as a prototype of an earthquake-resistant house. The lighting factor, temperature, and airflow settings are made naturally. Besides, this house has also equipped with a rainwater storage system and greywater treatment using a small, constructed wetland that allows the treated water used for watering gardens and fishponds. The budget spent to build this house was as low as possible so that the surrounding community can imitate the building for their house and disseminate eco-friendly housing.
\end{abstract}

This is an open access article under the CC BY-SA license

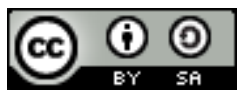

\section{Keywords:}

Choice;

Eco-friendly;

Housing;

Peri-urban;

Article History:

Received: February 11, 2021

Revised: April 11, 2021

Accepted: April 15, 2021

Published: April 30, 2021

\section{Corresponding Author:}

Allis Nurdini

School of Architecture,

Planning and Policy

Development, Institut Teknologi

Bandung, Indonesia

Email:allis@ar.itb.ac.id

\section{INTRODUCTION}

Housing is one of the biggest contributors to the emission of environmentally damaging gases such as carbon dioxide, methane and carbon monoxide [1, 2, 3]. The existence of this gas will encourage faster global warming if its existence is not controlled [4][5]. Along with the progress of the Indonesian nation, the need for environmentally friendly housing prototypes supporting 
sustainable housing, in the term of energy efficiency and integrated with water utility systems, livestock and agriculture on site is essential.

Sustainable housing has described as a house and residential neighborhood that considers several concepts includes:

(i) meet an aspect of health, durable, safe, and secure status (like from eviction);

(ii) affordable in term of social economy;

(iii) using local building materials and ecological technologies;

(iv) resilient in dealing with natural disasters and the impacts of climate change;

(v) connected to safe and affordable energy, water, sanitation, and utilities/facilities;

(vi) use of energy and water efficiently and are equipped with renewable/recycle energy, electricity and water;

(vii) minimize pollution to the environment and is protected from environmental pollution;

(viii) (viii) well connected to the workplace, commerce, health care and children's education, and other services;

(ix) integrated and able to improve the social, cultural, and economic structure in the surrounding environment and a wider urban area; and

(x) well managed and maintained until the housing renovation phase [6, 7, 8, 9, 10, 11].

Those concepts could be concluded in the term of eco-friendly housing as the balancing of health aspect, adaptive in process and affordability into the maintenance and renewal process of housing aspect. From those concepts, as shown in Figure 1, it is identified two key principles to build a prototype of eco-friendly housing. The first principle is the sense of social-economic and environmental sustainability. The second one about the fundamental aspect of housing choice is the freedom to build for everyone in terms of process and product term. Therefore, it is essential to develop a prototype for the community in rural and peri-urban to build environmentally friendly houses as part of together awareness and effort to reduce environmental pollution.

\section{MATERIAL AND METHOD}

\section{Eco-friendly Concept and Housing Choice in Term of Process and Product}

A sustainable home affects social, economic and environmental sustainability. A sustainable home is aimed at (i) improving the quality of life and the dignity of residence, (ii) increasing access to affordable housing, (iii) improve health and reduce mortality and material loss, and increase labor productivity better, (iv) ensuring better conditions for human development, employment, creativity and economic growth, (v) increased durability and lower maintenance costs, (vi) protection against the dangers of natural disasters, (vii) improve efficiency and save the use of energy, water and other physical resources, (viii) improved environmental protection and sanitary conditions, (ix) contribute to climate adaptation and mitigation; and (x) promote more sustainable and socially inclusive urban growth; and social cohesion and political stability [6, 8, 10, 11, 12, 13, 14].

The next main principle is in terms of freedom of choice in both processes and products. The relationship between social, economic, and environmental sustainability in a sustainable home cannot be separated from one another. This can depend on the existence of a house seen from the choice of side of the house as a process and the house as a product that affects each other. The housing process covers aspects of Planning, Design, Construction, Operations. Then the choice of housing products covers the aspects of physical, spatial, cultural and economic characteristics [6, $14,15,16,17,18]$. 


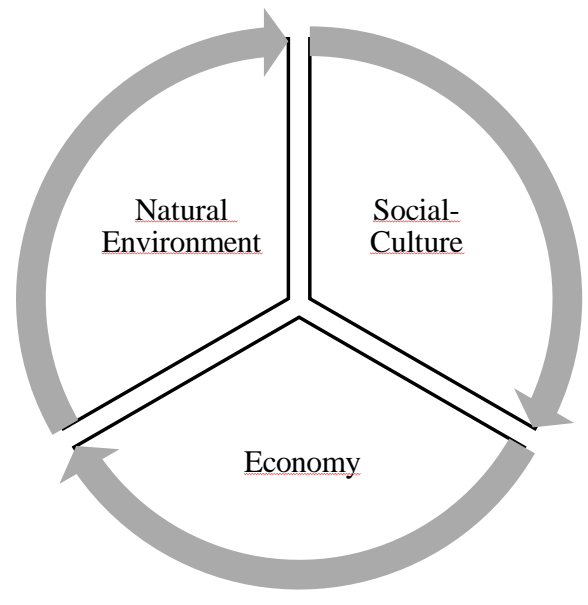

(i) The first principle: aspect balancing

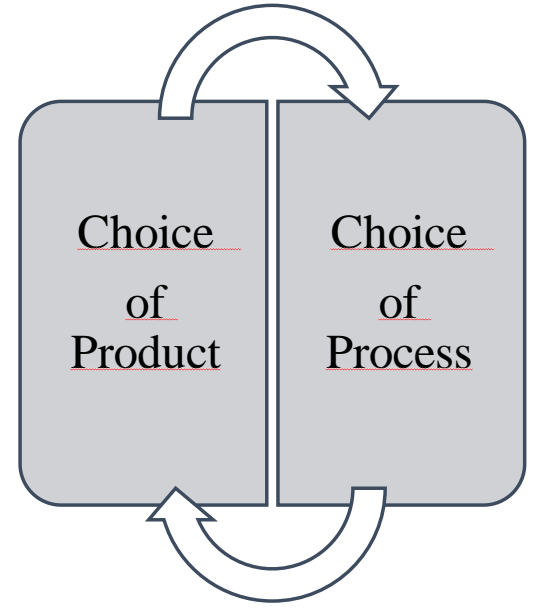

(ii) The second principle: freedom to choose

Figure 1. The principles of eco-friendly housing

\section{Method}

The methodology to conduct this study is research by design or action research that combines interdisciplinary aspect in the team such as architecture, civil engineering, life science, and bioengineering. There are several steps, including 1) Site identification and analysis, including determination of material, a system of building and site plan, and utility system for water, electricity and waste management; 2) Design phase that considers minimizing the land use for the buildable area, maximize the local material, such as using wood material in the site (Gmelina Arborea) that has been in consumption phase; bamboo wall from a local market, etc.); lower cost (local material, minimize transportation of material source and local worker); incremental and gradual development; and light structure for the second floor as consideration of adaptive structure for earthquake sensitivity; 3) Building or construction phase that considers affordable; local worker; flexible schedule and 4) Monitoring and evaluation phase.

\section{Analysis and Design}

The analysis and design process considers the choice of product and the choice of process. The choice of a product consists of the choice of building product (system and material) and the choice of utilities and facilities system.

\section{a. The choice of product}

Building products to be built can be selected based on the combination of building materials available around the construction site, from the selection of materials for building structures, wall coverings, and roof coverings. The choice of materials that can be used as a building structure includes materials made from wood and iron. For wall coverings, materials to choose from include wood, booths (woven bamboo), and plaster bricks. Meanwhile, for roof coverings, the materials to choose from are clay-based tiles and galvalume. 
Provision of utility system products and facilities can be selected based on the existing system, the procurement of new utility systems and facilities, or a combination of the existing system with the new procurement system. The systems implemented include clean water systems, wastewater systems, and gas-electrical systems.

\section{b. The choice of process}

Three process options can be used, including building a house that is done independently, mutual cooperation (gotong royong system), and the procurement of 3rd party service contracts (local workers) to construct a house. The scope of development carried out through the choice of the house construction process includes land preparation, procurement of structural and architectural materials, procurement of clean water systems, wastewater systems, and electrical systems.

\section{RESULT AND DISCUSSION}

The implemented concept for eco-friendly housing prototype building on ITB research garden laboratory at Haurgombong Village, Sumedang Regency, West Java Province, includes building and utility system. For the building concept, the main implemented aspects are:

(i) The building renovated from the existing toilet rooms ( $2 \times 3$ meter square) was built in 2007 with funding from LAPI ITB.

(ii) This building will have functioned as a prayer room, library, a place to stay for researchers or students who need several days of observation.

(iii) The wood material has been obtained from the trees of seven years old beechwood (Gmelina Arborea) planted in the garden.

(iv) The foundation and column structure on the ground floor uses reinforced concrete.

For the implemented utilities and site that eco-friendly based, it is conducted several aspects:

(i) a rainwater collection installation equipped with a filter and sedimentation system.

(ii) Gray water system that collected in 3 tiered ponds for cleaning in a phytoremediation system with various aquatic plants, then in the third pond fish. Besides, this water also can be used as a water reserve for watering plants.

(iii) The house has been designed by optimizing air circulation and natural lighting to reduce electricity for daylighting.

(iv) The fiberglass material used for some roofs as a source of lighting for plants planted hydroponically at the second-floor area.

(v) The fuel source for the kitchen will be integrated with the biogas installation installed. The distance between the house and the existing biogas installation is about 20 meters.

(vi) In the future, small-scale solar cell panels will be installed as a pilot project.

In Figure 2, there is the house site concept illustration. The area for building as minimize as possible attachment is proposed, and there are three ponds: wet water treatment pond (WWTP) Pond 1, WWTP Pond 2 and fishpond at the first-floor plan. There are a common room and balcony on the second-floor plan, and there is a mezzanine floor for the bedroom. 


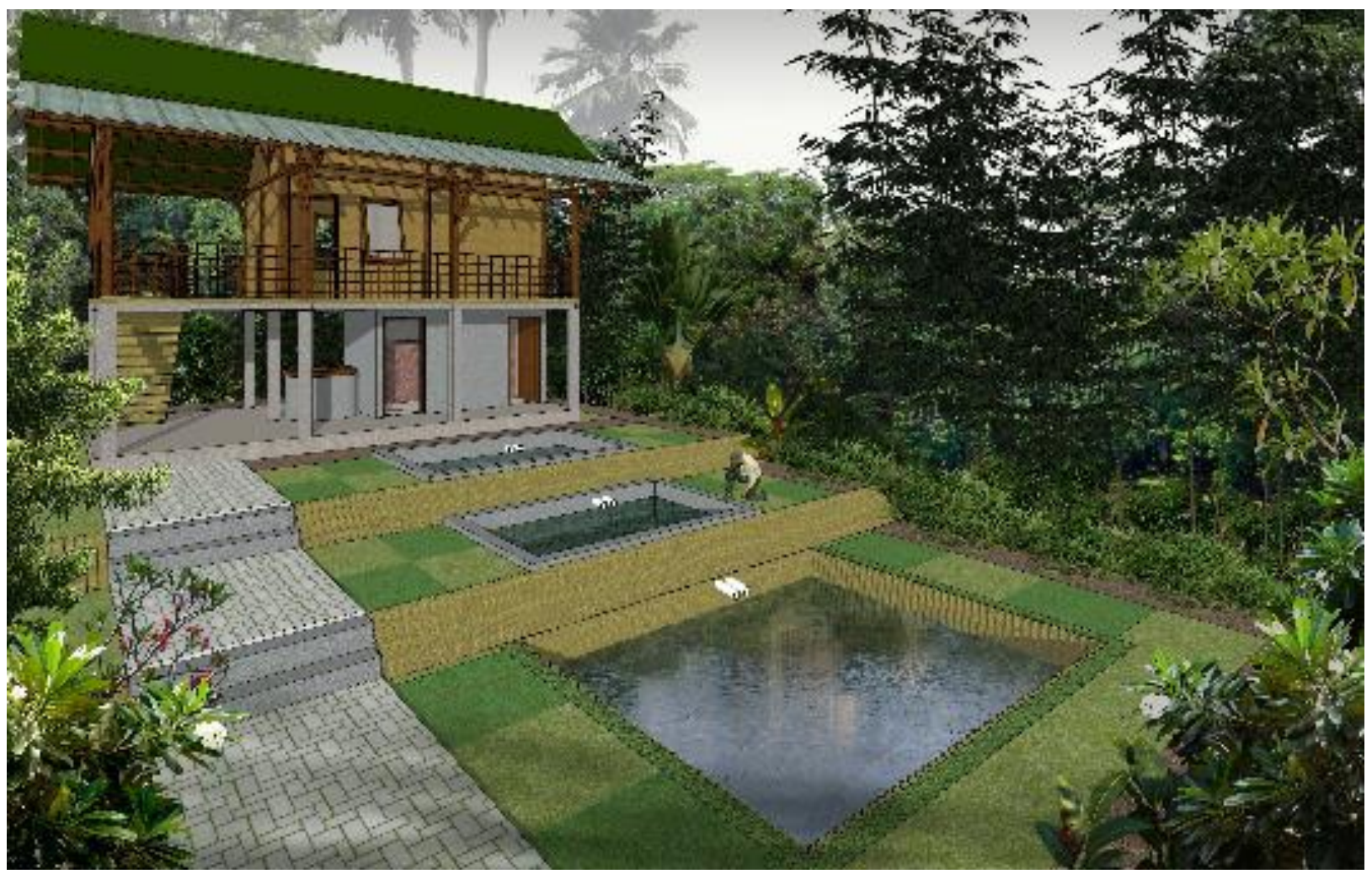

Figure 2. The eco-friendly house site concept

There is some photo documentation of the construction or implementation phase, as depicted in Figure 3. Start from site preparation on July 2020, the structural phase for foundation-beam and column construction, the total structure until roof structure builds up, and the stair construction until the coverage wall from bamboo material is done on $17^{\text {th }}$ November 2020 . There is also documentation of fishpond construction, the two drum for rainwater harvesting, and the cow manure/dung reservoir to process and produce biogas. The total cost for the building, pond and utilities was approximately around 25 million rupiahs. On $19^{\text {th }}$ November, this house was launched by ITB vice director of research and community service institution. There is the full team researcher, invited community and the final building figure. The community surrounding this facility could come, join several activities, and hopefully imitate this housing prototype.

For this action research, there are some implemented principles related to the ecological friendly system. Overall, the total of the implemented principles could be seen in Table 1. 

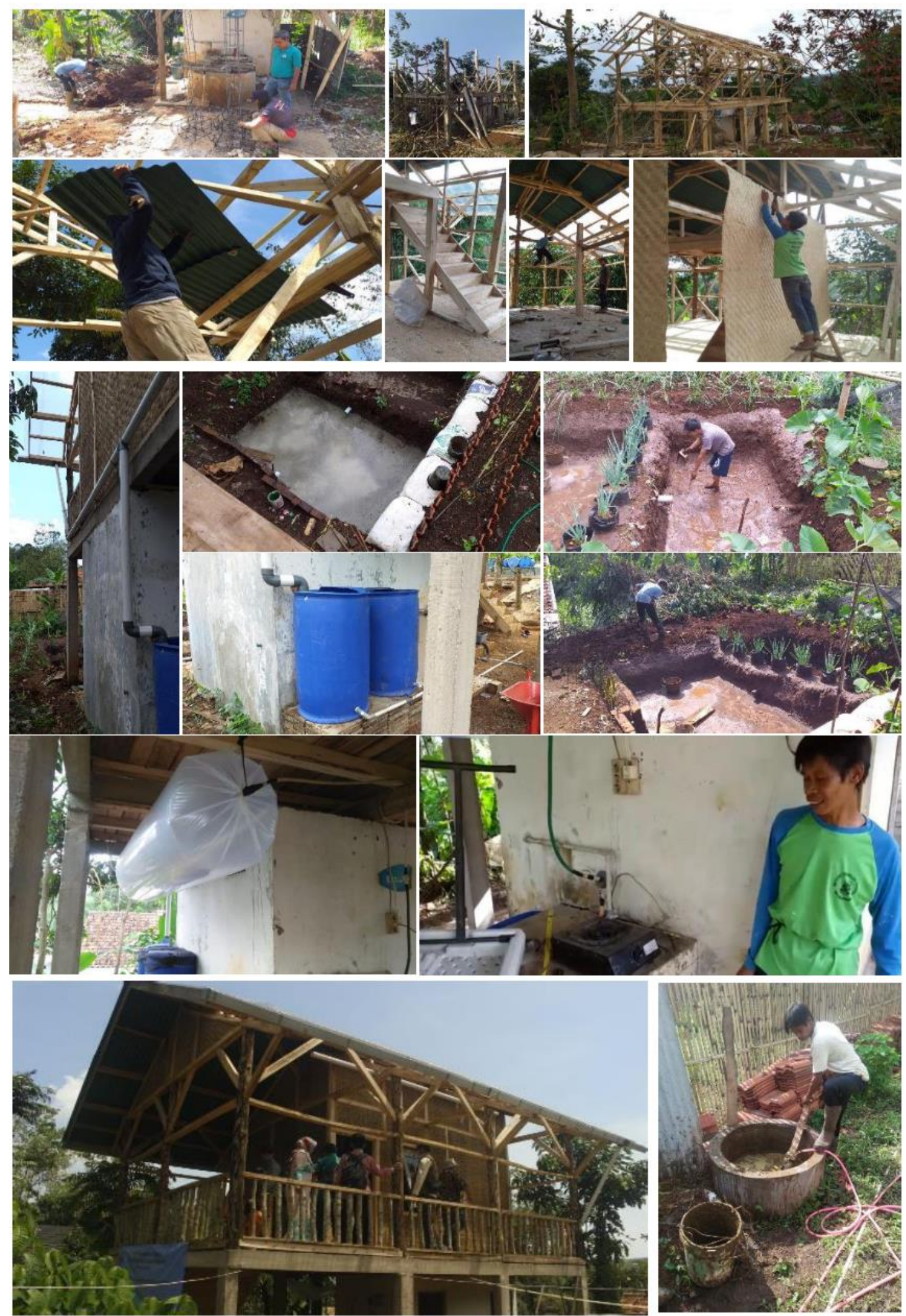

Figure 3. The implementation of eco-friendly housing 
Table 1. The Choice Scheme of Implemented Eco-friendly Housing

\begin{tabular}{l} 
The choice of product \\
Description \\
\cline { 2 - 5 }
\end{tabular}

\section{CONCLUSION}

There are some key-points as lesson learned, including: 1) The need of smart site identification and analysis like potential mapping of local material, local system of building and site plan, and sustainability/circular utilities for energy, water, waste; 2) The need of integrated discipline for housing design perspective; such as concept to minimize the land use for buildable area, the adaptive concept for Earthquake sensitive; to maximize the local material especially wood and bamboo; that should be integrated with cycles program for wood tree from seed, growth and consumption phase; to lowering building cost (local material, minimize transportation of material source and local worker) and to make big opportunity for user for incremental and gradual development; and 3) The need of freedom to build as community choice for product and process this include sense of affordability, local worker and possibility of "gotong royong" system, and to open possibility of flexible schedule for housing system.

\section{REFERENCES}

[1] P. Wilkinson et al., "Public health benefits of strategies to reduce greenhouse-gas emissions: household energy," The Lancet, vol. 374, no. 9705, pp. 1917-1929, 2009, doi: 10.1016/S0140-6736(09)61713-X

[2] C. Kuang, "Analysis of Green House Gases and Positive Impact of Replacing Traditional Energy with Clean Energy," E3S Web of Conferences, 2021, vol. 241, ID: 02005, pp. 5, doi: 10.1051/e3sconf/202124102005

[3] D. D. P. Preethia et al., "Energy Management Contribution for Green House Gas Mitigation," Journal of Research Technology and Engineering, vol. 2, no. 2, pp. 1-31, 2021

[4] C. Folke et al.,'Our future in the Anthropocene biosphere," Ambio, vol. 50, pp. 834-869, 2021, doi: 10.1007/ s13280-021-01544-8

[5] A. Azam et al., "Analyzing the effect of natural gas, nuclear energy and renewable energy on GDP and carbon emissions: A multi-variate panel data analysis," Energy, vol. 219, ID: 119592, 2021, doi: 10.1016/j.energy. 2020.119592

[6] O. Golubchikov, and A. Badyina. "Sustainable housing for sustainable cities: a policy framework for developing countries," United Nations Human Settlements Programme 2012, Nairobi, Kenya: UN-HABITAT, 2012

[7] C. L. Choguill, (2007). The search for policies to support sustainable housing. Habitat International, 31(1), 143-149 
[8] E. O. Ibem, and B. E. Aduwo. "Urban housing and social development in Nigeria: issues and prospects." Developing Countries, Political, Economic \& Social Issues, Hauppauge: Nova, 2013, pp: 69-96

[9] H. Chen, S. Ganesan, \& B. Jia, "Environmental challenges of post-reform housing development in Beijing," Habitat International, vol. 29, no. 3, pp. 571-589, 2005, doi: 10.1016/j.habitatint.2004.05.002

[10] C. Pugh, Sustainability, the environment and urbanization, $1^{\text {st }}$ Ed., Earthscan, Routledge, UK, 1996

[11] D. A. Turcotte and K. Geiser, "A framework to guide sustainable housing development," Housing and Society, vol. 37, no. 2, pp. 87-117, 2010, doi: 10.1080/08882746.2010.11430582

[12] I. A. Okewole and A. Aribigbola, "Innovations and sustainability in housing policy conception and implementation in Nigeria," The built environment: Innovation policy and sustainable development, pp. 414420, 2006

[13] C. Day and S. Roaf, Ecohouse: a design guide, Routledge, UK, 2007

[14] S. Roaf, M. Fuentes, and S. Thomas, Ecohouse: A Design Guided, Architectural Press, US, 2001

[15] S. Roshanfekr, N. M. Tawil, and N. A. Goh. "Investigation of sustainable housing criteria." MATEC Web of Conferences, vol. 66, ID: 00096, pp. 1-5, 2016, doi: 10.1051/matecconf/20166600096

[16] B. Purvis, Y. Mao, and D. Robinson, "Three pillars of sustainability: in search of conceptual origins," Sustainability Science, vol. 14, pp. 681-695, 2019, doi: 10.1007/s11625-018-0627-5

[17] A. E. O. Ibem and E. B. Aduwo, "A framework for understanding sustainable housing for policy development and practical actions." Architects Registration Council of Nigeria (ARCON), Nigeria, 2015, pp. 1-19

[18] C. Choguill, "Sustainable housing programmes in a world of readjustment," Habitat International, vol. 18, no. 2, pp. 1-11, 1994 